\title{
A bathymetric, magnetic and gravity survey of the Rockall Bank
}

\section{The Hydrographic Department}

\author{
Ministry of Defence, Taunton, Somerset, U.K.
}

In two periods, March-May and September-November, 1969, H.M. Surveying Ship Hecla systematically surveyed the Rockall Bank. The main scientific and surveying aims of the project were:

(a) To delineate the topography of the bank

(b) To map in detail the complex magnetic fields over the bank

(c) To map the variations in the free-air gravity anomaly on the bank

(d) To obtain sea-surface temperature and salinity data at regular intervals during the survey.

The data obtained during the survey have been published by the Hydrographer in the form of four charts and one Admiralty Marine Science Publication; these form the basis of the Poster Presentation. The charts, all at a scale of 1:250,000 are: C6091-Bathymetry; C6091A-Free-air gravity anomalies (transparent overlay); C6091B-Total magnetic intensity (transparent overlay); C6091CMagnetic Anomalies (transparent overlay).

The Admiralty Marine Science Publication is entitled A Bathymetric, Magnetic and gravity survey of the Rockall Bank H.M.S. Hecla 1969 and is by D. G. Roberts and M. T. Jones, published in Taunton in 1978. It is publication NP 650 (19). The report is concerned primarily with a narrative of the survey and detailed descriptions of the instrumentation and data-reduction methods used in the production of the charts of the Rockall Bank. The geophysical surveying equipment consisted of an Admiralty-type 773 echo-sounder and a Kelvin Hughes MS 38 recorder, a Varian Associates Direct Reading proton magnetometer and a Graf Askania GSS 2 seagravimeter.

The survey lines were originally spaced 2.5 miles apart in a $90^{\circ}$ or $270^{\circ}$ direction, although these were subsequently interlined to give a track spacing of 1.25 miles. In areas of rough bottom topography with depths of less than 100 fathoms, interlines were run at 0.6 mile line spacing and at 0.3 mile line spacing in the immediate vicinity of Rockall Island.

Continuous observations of depth, total magnetic field intensity, sea-surface temperature, wet and dry air temperatures, and solar radiation were taken throughout the survey and on passage to and from the survey area. Some of these data were recorded on the Automatic Data Logging System.

Examination of the magnetic anomaly chart and profiles shows two major different and distinctive discontinuities that separate areas of contrasting magnetic character. South of a 10 mile wide, approximately east-west trending discontinuity at $56^{\circ} 40^{\prime} \mathrm{N}$ the magnetic anomalies are highly irregular in both wavelength and amplitude in contrast to those in the north. This discontinuity, though less apparent in the gravity anomalies, may be a fault or the trace of an unconformity that separates the Lewisian rocks known to outcrop on Empress of Britain Bank from the extensive lava flows to the north. 
North of this discontinuity, the anomalies are characteristically of short wavelength and large amplitude and can rarely be continuously correlated for more than five miles. Four areas of exceptionally complex character can be seen: around Rockall Island the anomalies have a distinctive pattern due to ring dykes associated with the eroded volcano and are associated with a positive $128 \mathrm{mgal}$ gravity anomaly. Further south the other areas, which also form the shoals, may represent similar intrusive complexes although there are no major gravity anomalies associated with them. However, it is possible that these areas may be inliers of metamorphic rocks surrounded by lava flows.

Copies of the charts and the report can be obtained from Admiralty Chart Agents.

\section{Drifting buoys in the Rockall Trough}

\section{Booth and D. Meldrum}

Dunstaffnage Marine Research Laboratory, P.O. Box 3, Oban, Argyll PA34 4AD, Scotland

A series of drifting buoys, tracked by satellite and drogued at depths between $15 \mathrm{~m}$ and $165 \mathrm{~m}$, have been released in Rockall Trough. The buoys were specifically designed for current measurement and have a low wind drag.

Results show a general northeastward drift from Rockall Trough into the Norwegian Sea via the Faeroe-Shetland Channel, as expected. The total transport of near surface Atlantic water through the Faeroe-Shetland Channel is estimated to be about $3 \times 10^{6} \mathrm{~m}^{3} \mathrm{~s}^{-1}$. Six buoys then travelled northeastwards along the Norwegian coast, but two buoys followed topography down into the Norwegian Trench, and became trapped in the mixing between warm Atlantic water and cool Norwegian coastal water.

Topographic guiding was also apparent in Rockall Trough, both at the Scottish continental slope and around the banks such as Rockall and Hatton, generally with shallow water to the right of the current direction. Away from steep topography, currents were weak except in eddies which were mainly found in two areas, northwest of Porcupine and around Anton Dohrn Seamount. Observed current speeds in the eddies were about $0.5 \mathrm{~m} \mathrm{~s}^{-1}$ with periods between 1 and 6 days. Eddy radii ranged from $7 \mathrm{~km}$ to $50 \mathrm{~km}$, comparable to the scale of temperature anomalies apparent on IR satellite images. This scale is about the internal deformation radius and the eddy formation mechanism is likely to include baroclinic instability. The small cyclonic eddies found near Anton Dohrn are probably shed from a Taylor column generated above the Seamount.

Tagging near surface water of Rockall Trough with drifting buoys has left us an impression of areas of strong circular eddy motion and regions of strong comparatively steady flow above topographic guiding, between which the flows have an irregular interweaving nature, and are perhaps the remnants of decayed instabilities and eddies producing large scale mixing. 